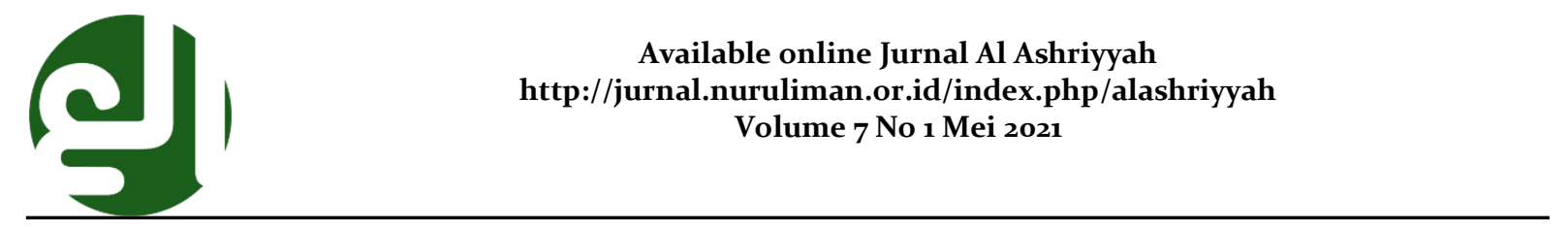

\title{
PERDEBATAN IMAN DAN KUFURNYA FIR'AUN PERSPEKTIF MUFASIR DAN SUFISTIK
}

\author{
Saepudin, Muhammad Waliyullah \\ Sekolah Tinggi Agama Islam Nurul Iman
}

Jl. Nurul Iman No. 1 Ds. Warujaya Rt. o1/o1 Kec. Parung Kab. Bogor 16330

Email: saefudinasfa@gmail.com, umarfauzi@stai-nuruliman.ac.id

No. Tlp/WA: xxx xxx xxx

Diterima: 11 April 2021; Diperbaiki: 18 April 2021; Disetujui: 20 April 2021

\begin{abstract}
Pharaoh was a title for the king of ancient Egypt. Many of his stories are mentioned in the Qur'an, he is mentioned as a ruler who has bad attitudes, however, behind that the alQur'an explains that when he died, he had the opportunity to make his faith and Islam plausible. Then what is the state of faith that he offered? al-Khazin (2004) stated that the repentance of Pharaoh was not accepted by Allah SWT because at that time there was no more time to repent. In contrast to Dawani (W. 1512 AD), he stated that his repentance was accepted because he made a vow before the spirit reached the throat. If viewed from two conditions about faith, namely there is a pledge and justification in the heart (Ibrahim Mustafa, $1370 \mathrm{H}$ ), then Pharaoh has met these criteria. The author tries to analyze these two problems by using the interpretation method tafsir maudhû' $i$ ". The faith made at the end of life is the closing of a good life, and the al-Qur'an explains the end of the life of Pharaoh by pledging to believe and surrender to Allah SWT (QS. Yûnus / 10: 90).
\end{abstract}

Keywords: Pharaoh, Faith, Kufur.

Abstrak

Fir'aun adalah suatu gelar bagi raja Mesir kuno. Kisahnya banyak disebutkan dalam alQur'an, ia disebutkan sebagai sosok penguasa yang memiliki sikap-sikap yang buruk, namun, dibalik itu al-Qur'an menjelaskan bahwa ketika menjelang ajalnya, ia berkesempatan mengikrarkan keimanan dan keislamannya. Lalu bagaimanakah keadaan iman yang ia ikrarkan tersebut?. al-Khazin (2004) menyatakan, bahwa taubatnya Fir'aun tidak diterima oleh Allah SWT karena di saat itu sudah tidak ada lagi waktu untuk bertaubat. Berbeda dengan al-Dawani (W. $1512 \mathrm{M}$ ), ia menyatakan bahwa taubatnya diterima karena ia berikrar sebelum ruh sampai di tenggorokan. Jika dilihat dari dua syarat tentang iman yaitu ada ikrar dan pembenaran dalam hati (Ibrahim Mustafa, 1370 H), maka Fir'aun sudah memenuhi kriteria tersebut. Penulis mencoba menganalisis dua permasalahan tersebut dengan menggunakan metode tafsir maudhûî́. Keimanan yang diikrarkan di akhir hayat adalah merupakan penutup kehidupan yang baik, dan al-Qur'an menjelaskan akhir kehidupan Fir'aun dengan ikrar beriman dan berserah diri kepada Allah SWT (Q.S Yûnus/10:90).

Kata Kunci : Fir'aun, Iman, Kufur. 


\section{Pendahuluan}

Fir'aun adalah sosok penguasa yang paling banyak disebut dalam alQur'an. Al-Qur'an menggambarkannya pribadinya pada dua keadaan, keadaan pada masa hidupnya sebagai penguasa Mesir yang bersikap buruk, di antaranya; melakukan pembunuhan terhadap bayi laki-laki, melakukan intimidasi terhadap Bangsa Israil, dan hal terbesar adalah sebagai seorang yang kufur terhadap ajaran tauhid yang dibawa Musa as. Namun, di sisi lain alQur'an menegaskan bahwa Fir'aun sempat mengikrarkan keimanan dan keislamannya di saat menjelang kematiannya (Q.S Yunus/10:90).

Al-Qur'an sebagai kalam Allah yang memiliki makna lahir dan batin tentu dalam penafsiran terhadapnya tidak akan berakhir pada satu penafsiran. Perbedaan dalam menafsirkan ayat adalah hal yang sangat mungkin terlebih latar belakang penafsir pasti akan mempengaruhi tafsirannya. Keadaan seperti itu yang di antaranya menjadi dasar terjadi perbedaan penafsiran terhadap ayatayat seputar Fir'aun terlebih pada Surat Yunus/10:9o.

Di antara mufasir menyatakan dalam menafsirkan Surat Yunus/10:90 bahwasannya keimanan yang diikrarkan Fir'aun tidak diterima oleh Allah SWT sehingga ia mati dalam keadaan kafir. ${ }^{1}$ Berbeda halnya dengan sufistik, mereka menyatakan bahwa Fir'aun meninggal dalam keadaan

\footnotetext{
${ }^{1}$ Muhammad bin Ahmad al-Qurtubi, al-Jâmi' al-Ahkâm al-Qu'rân, Jilid IV (Bairut: Maktabah al-Muassasah, 2006), h. 153.
}

beriman karena hal itu secara tegas dijelaskan dalam ayat. ${ }^{2}$

Dua hal inilah yang mendasari penulis tergugah untuk menggali tentang dasar-dasar yang menjadi argumen mereka dalam memberikan pernyataan-pernyatan seputar iman dan kufurnya Fir'aun.

\section{Pembahasan}

\section{Perdebatan Iman dan Kufurnya} Fir'aun Perspektif Mufasir dan Sufistik

Tidak sedikit ayat-ayat yang menjelaskan bahwa Fir'aun adalah seorang yang kafir dengan melakukan penentangan kepada Musa as. Dan pada ayat lain ditegaskan pula bahwa dirinya berkesempatan mengikrarkan keiman dan keislamannya. Dua hal tersebut yang menimbulkan pro dan kontra antar penafsir. Kelompok pertama menyatakan bahwa ikrar dan pengakuan keimanan Fir'aun tidak diterima oleh Allah SWT. sehingga ia dikategorikan sebagai golongan orangorang yang kafir kepada Allah SWT. Kelompok ini didukung para mufasir di antaranya oleh al-Thabari, al-Alusi, Ibnu Kasir, al-Nasa'i, dan lainnya. Kelompok kedua menyatakan bahwa pengakuan keimanan Fir'aun diterima oleh Allah SWT sehingga ia dikategorikan orang-orang yang beriman kepada Allah SWT. Kelompok ini didukung oleh sufistik di antaranya Ibnu 'Arabi yang ia dikenal sebagai

\footnotetext{
${ }^{2}$ Jalaluddin Al-Dawani, Risalah Iman Fir'aun, Cet. I (Mathba'ah al-Mishriyyah, 1964), h. 16 .
} 
tokoh paham wahdah al-wujud, ${ }^{3}$ Syekh Abdurrahman Nuruddin sebagai pensyarah kitab Fushûsh al-Hikam, Jalaluddin al-Dawani, al-Baqilani keduanya merupakan tokoh ilmu kalam dan filosof, dan Mahmud al-Gurab. Selain mereka ada sebagian dari para pengikut madzhab Hanabilah. ${ }^{4}$

Secara mendasar yang menjadi sumber perdebatan ulama dan akademisi terkait iman dan kufurnya Fir'aun adalah Surat Yunus ayat 9o. Namun mesti demikian bukan berarti pada ayat lain tidak ada perdebatan terkait iman dan kufurnya Fir'aun. Karena setiap ayat tentu memiliki keterkaitan satu sama lain.

\section{A. Pendapat Mufasir}

Kelompok ini menyatakan bahwa ikrar keimanan Fir'aun tidak diterima oleh Allah SWT. Mereka berargumen dengan berdasarkan pada dalil-dalil naqli baik ayat alQur'an atau pun hadis Nabi Muhammad SAW. dan ada juga yang berargumen berdasarkan aqli atau logika yang diistinbathkan kepada dalil naqli.

Menurut al-Alusi kalimat alidrâk pada ayat tersebut memiliki arti al-luhûq atau terkena yaitu terkenanya Fir'aun oleh terjangan ombak yang akan membinasakan sehinngga dengan kalimat al-idrak

3 Syamsuddin al-Salafii al-Afganii, Juhûdu 'Ulama al-Hanafiyyah fî Ibthâl 'Aqâ'id alQubûriyyah (Riyad: Dar as-Syami'i, 1996), h. 1325 .

${ }^{4}$ Abd al-Wahab al-Sya'rani, al-Yawaqit wa al-Jawahir, Juz II (Bairut: Dar al-Kutub alIlmiyyah, 2013), h. 380. tersebut menjadi batallah kalimat âmantu -ikrar imannya Fir'aun-. Menurutnya kata al-idrak secara tersirat menunjukan ikrar imannya Fir'aun- âmantu- itu terjadi ketika ia jatuh tenggelam diterjang oleh ombak, sehingga pada kalimat âmantu itu ada kemungkinan merupakan ungkapan al-kalâm alnafsi-. ${ }^{5}$

Senanda dengan pendapat Ibnu Asyur. Ia mengatakan bahwa kata alidhrâk selain berarti al-lihâq dapat berarti berakhirnya perjalanan. Kata tersebut memberitahukan bahwa yang dimaksud kata "tenggelam" adalah secara berangsur dengan goncangan laut dan terpaan ombak. Sehingga dalam keadaan seperti itu tidak ada harapan selamat dan muncul rasa putus asa lalu diikrarkanlah keimanan oleh Fir'aun. ${ }^{6}$

Imam al-Thabari dan Imam alKhazin sependapat bahwa ikrar iman yang dilakukan Fir'aun hanya sekedar dengan harapan supaya dia dapat terlepas dan selamat dari bencana yang menimpanya yaitu ombak besar yang akan menenggelamkan dirinya di tengah lautan. ${ }^{7}$

Adapun hadis yang menjelaskan tentang Malaikat Jibril

5 Al-Alussi, Tafîr Rûh al-Ma'âni, ..., Jilid.11, h. 181.

${ }^{6}$ Ibnu 'Asyur, Tafsir al-Tahrir wa alTanwir, Juz XI, t.t., h. 25.

7 Ibnu Jarir al-Thabari, Tafsîr alThabari, Jâmi al-Bayâ, Juz Xii (Kairo: Dâr Hijr, 2001), h. 279. Lihat dalam Ibrahim al-Bagdadi, Tafsîr al-Khâzin, Bairut: Dâr al-Kutub alIlmiyyah, 2004, juz. 2, h. 460. 
turun dan mengambil lumpur untuk disumpalkan pada mulut Fir'aun karena khawatir mendapat rahmat dari Allah SWT. al-Razi memberikan komentar atas kejanggalan-kejanggalan pada hadis tersebut. Di antara komentarnya, jika Jibril menyumpal mulut Fir'aun dengan tujuan untuk menghalanginya dari mengikrarkan keimanannya berarti ia menghalangi hamba untuk bertaubat padahal tidak boleh Jibril menolak siapapun untuk bertaubat bahkan dia harus menolongnya untuk bertaubat. Terhadap hal ini al-Razi berpedoman pada Surah al-Ma'idah/5:2. ${ }^{8}$ Bahkan menurutnya walaupun Jibril menahan dengan sumpalan tanah di mulut Fir'aun maka taubat tetap mungkin dilakukan karena orang bisu pun dia bisa bertaubat dengan adanya penyesalan di hati. Selain itu seandainya Jibril menghalangi taubatnya Fir'aun berarti ia ridha terhadap kekufuran. Sedangkan ridha terhadap kekufuran berarti telah kufur. ${ }^{9}$ Dan juga tidak layak

\footnotetext{
${ }^{8}$ Teks ayat sebagai berikut:

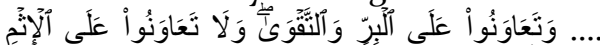

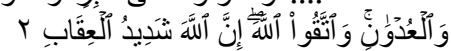

“...... Dan tolong-menolonglah kamu
} dalam (mengerjakan) kebajikan dan takwa, dan jangan tolong-menolong dalam berbuat dosa dan pelanggaran. Dan bertakwalah kamu kepada Allah, sesungguhnya Allah amat berat siksa-Nya”. (Q.S al-Ma'idah:2).

${ }^{9}$ Pendapat ini dijelaskan juga oleh azZamaksyari dalam tafsirnya al-Kasyaf, ia berkata "sesungguhnya orang yang tidak senang terhadap berimannya orang kafir dan bahkan senanng tetapnya kufur bagi dia maka orang tersebut telah kafir. Karena ridha dengan kekafiran adalah kufur. Perbedaan dengan alRazi terletak pada teks hadis. Al-Zamaksyari
Allah berfirman kepada Musa as dan Harun as "faqulâ lau qaulan layyinan la'allahu yatadzakkaru au yakhsya" yang kemudian Dia perintahkan kepada Jibril untuk menghalangi Fir'aun dari iman. Ataupun seandainya ada yang berpendapat bahwa yang dilakukan Jibril adalah dari kehendak dirinya-bukan dari perintah Allah SWT maka hal ini ditentang oleh perkataan Jibril dalam firman Allah SWT “ wa mâ natanazzalu illâ bi amri rabbik"kemudian firman-Nya "wa hum min khasyatihi musyfiqûn" dan firman-Nya "lâ yasbiqûnahu bi alqauli wa hum bi amrihi ya'malûn" dan jika memang di waktu itu sudah tidak ada lagi taklif bagi Fir'aun maka yang dilakukan Jibril sama sekali tidak ada faidah dan manfaatnya. ${ }^{10}$

Komentar Imam al-Razi terhadap hadis tersebut menunjukan bahwa ia tidak menggunakan dalil itu sebagai argumen. Hal itu terlihat dari beberapa komentar yang disampaikannya mengindikasikan bahwa ia terlihat bersikap netral dalam arti lain ia tidak memberikan satu pernyataan yang pasti bahwa dengan hadis ini menandakan iman Fir'aun diterima atau tidak. Sebab

menyebutkan penggalan akhir dari hadis yang berbunyi "kekhawatiran Fir'aun akan mendapat rahmat dari Allah SWT". menurutnya adalah hanya sekedar tambahan dari orang-orang yang berdusta kepada Allah dan Malaikat-Nya. Sehingga bantahannya di atas merupakan jawaban terhadap munculnya kebodohan. Lihat al-Zamaksyari, Tafsir al-Kasyâf,...juz. 3, h. 171

${ }^{10}$ Lihat al-Fahr al-Razi, Tafsîr al-Kabîr, .......jilid. 17, h. 155. 
komentarnya-terhadap hadis tersebut-tidak memberi keputusan yang final dalam masalah yang dilakukan Malaikat Jibril terhadap Fir'aun. Namun mesti demikian ia tetap mengkafirkan Fir'aun yaitu dengan menguraikan argumen dari ra'yi atau pun ayat yang berkaitan degan taubat.

Selain dari dua sebab di atas ada juga alasan lain yang dijadikan argumen dalam memperkuat pendapat mereka terkait penyebab ikrar Fir'aun tidak diterima oleh Allah SWT yakni terkait taubatnya. Adapun ikrar iman Firaun diidentikan dengan pertaubatannya, karena taubat berarti kembali, yaitu kembali kepada Allah SWT." Selain itu, dengan menganalisa pendapatpendapat mufassir yang mereka melakukan bantahan terhadap pernyataan bahwa Fir'aun mati dalam keadaan beriman dengan menggunakan ayat-ayat taubat.

\section{B. Pendapat Sufistik}

Golongan sufistik yang menyatakan bahwa ikrar Fir'aun diterima oleh Allah SWT di antaranya adalah Ibnu Arabi. ${ }^{12}$ Ia adalah seorang sufi yang

${ }^{11}$ Ibnu al-Faris, Mu’jam Maqâyîs alLughah, Jilid I (Bairut: Dar al-Jail, t.t.), h. 357.

${ }^{12}$ Ibnu Arabi seorang sufi yang produktif dalam karya dibidang tasawufnya beliau juga menyusun karya dalam bidang tafsir yang dikenal dengan tafsir Ibnu Arabi, namun dalam kajian seputar Fir'aun ini justeru pembahasan yang disuguhkan dalam tafsirnya tidak begitu lengkap dan detail. Namun Ibnu Arabi menguraikan secara spesifik dalam dua karyanya yang fenomenal yaitu al-Futûhât alMakiyyah dan Fushûshu al-Hikam. pernyataannya banyak mengungkap rahasia-rahasia yang tersirat dalam ayat-ayat maupun hadis. Hal itu terlihat dari ungkapanya yang dituangkan dalam karya besarnya alFutuhat al-Makiyyah. Ia berkata "sirrun ilahiyyun lâ ya'rifuhu katsîrun man al-nâs" "sebagai rahasia Allah SWT yang kebanyakan manusia tidak mengetahuinya”. Ungkapan tersebut ia sampaikan dalam menjelaskan ayat-ayat yang berkaitan dengan diutusnya Musa as dan Harun as kepada Fir'aun. ${ }^{13}$ Ia menyampaikan gagasan dalam menafsirkan ayat-ayat seputar Fir'aun yang berbeda dari para penafsir lainnya.

Terhadap Yunus/10:9o Ibnu Arabi mengatakan bahwa ucapan yang diungkap Fir'aun tersebut merupakan ungkapan yang sebenarnya muncul dari keyakinan yang memang ada sebelumnya pada diri Fir'aun, pendapatnya itu disandarkan dengan kata setelahnya yaitu "âl'âna" "sekarang-kamu beriman-“yang merupakan kata penetapan dan pengukuhan terhadap keimanan yang sudah ada sejak Musa as dan Harun as datang atas perintah Allah SWT untuk mengajaknya dengan cara lemah lembut. Sebagaimana dijelaskan dalam Surat Taha ayat 44. Allah SWT berfirman:

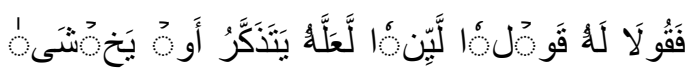

$\varepsilon \varepsilon$

${ }^{13}$ Ibnu Arabi, al-Futûhât al-Makiyyah, Jilid VI, Bab ke 386, t.t., h. 345. 
Maka berbicaralah kamu berdua kepadanya dengan kata-kata yang lemah lembut, mudah-mudahan ia ingat atau takut. (Q.S Taha/20:44).

Menurut Ibnu Arabi, yang perlu diperhatikan pada ayat tersebut adalah kata la'allahu. Ia mengatakan bahwa kata la'alla yang disandarkan kepada Allah SWT sudah menjadi kesepakatan jumhur ulama memiliki makana wâqi atau pasti. Seperti halnya kata 'asâ pada ayat "asâ Allahu an yatûba 'alaihim" "pasti Allah akan menerima taubatnya mereka". (Q.S alTaubah/9:102). Sehingga kata yatadzakkar -mengambil pelajarandan yakhsya-rasa takut kepada Allah- keduanya sudah ada pada diri Fir'aun. ${ }^{14}$ Sehingga makna yang dapat dipahami dari penjelasan tersebut menjadi "maka berkatalah kalian berdua kepadanya dengan perkataan yang lemah lembut pastilah ia menjadi ingat dan takutkepada Allah SWT-. Dan ayat ini dijadikannya sebagai penguat terhadap Surat Yunus ayat 9o.

Selain itu Ibnu Arabi juga memberi bantahan terhadap mufasir yang berargumen dengan Surat alGâfir ayat 85 yang mereka menyatakan bahwa iman yang diikrarkan Fir'aun tertolak karena dia berikrar di akhir hayat ketika menyaksikan bencana besar. ${ }^{15}$

${ }^{14}$ Ibnu Arabi, al-Futûhât al-Makiyyah ,...Jilid. 6, Bab ke 386, h. 345 .

${ }^{15}$ Wahbah al-Zuhaili, al-Tafsîr al-Munîr fí al-'Aqîdah wa al-Syarî'ah wa al-Manhaj,...juz. 6, h. 278.
Menurut mereka pengakuan keimanan yang dilakukan ketika mengahadapi bencana besar maka imannya tidak diterima.

Ibnu Arabi menafsirkan ayat 85 Surat al-Ghafir pada kalimat "falam yaku yanfa'uhum îmânuhum" menurutnya adalah iman itu tidak akan menyelamtakan seseorang dari adzab Allah SWT di bumi karena iman tidak dapat menolak turunnya adzab dari Allah SWT. ${ }^{16}$ Oleh sebab itu Allah tetap menenggelamkan Fir'aun walaupun ia sudah mengikrarkan keimanannya dan mengaku sebagai hamba yang berserah diri kepada Allah SWT. Jadi imannya Fir'aun itu tidak dapat memberikan kemanfaatan bagi dirinya dalam menghadapi bencana. Dengan kata lain ikrar keimanannya itu tidak bisa menyelamatkannya dari bencana besar ituditenggelamkan oleh Allah SWTbukan berarti keimanannya itu tidak diterima. ${ }^{17}$

Dari pernyataan di atas dapat dipahami bahwa iman yang sudah ada pada diri siapapun tidak bisa menolong dan menyelamatkannya dari siksa atau bencana yang Allah SWT timpakan kepada mereka di bumi. Kecuali hal itu hanya terjadi bagi umat Nabi Yunus as secara khusus. Sebagaimana dijelaskan dalam Surat Yunus ayat 98. Allah SWT berfirman:

${ }^{16}$ Ibnu Arabi, al-Futûhât al-Makiyyah ,...Jilid. 6, Bab ke 386, h. 346.

${ }^{17}$ Lihat Ibnu 'Arabi, al-Futûhât alMakiyah,...jilid. 6, h. 37. Lihat Ibnu Arabi Fushus al-hikam, ...h. 500. 


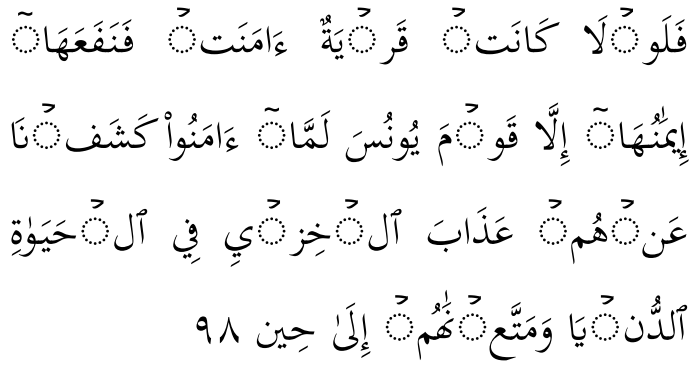

Dan mengapa tidak ada (penduduk) suatu kota yang beriman, lalu imannya itu bermanfaat kepadanya selain kaum Yunus? Tatkala mereka (kaum Yunus itu), beriman, Kami hilangkan dari mereka azab yang menghinakan dalam kehidupan dunia, dan Kami beri kesenangan kepada mereka sampai kepada waktu yang tertentu. (Q.S Yunus/10:98).

Ibnu Arabi menjelaskan lebih jauh bahwa keimanan yang dapat memberikan manfaat dan mencegah dari bencana yang terjadi di bumi itu terjadi pada kaum Nabi Yunus as hal itu ditegaskan dalam Firman-Nya:

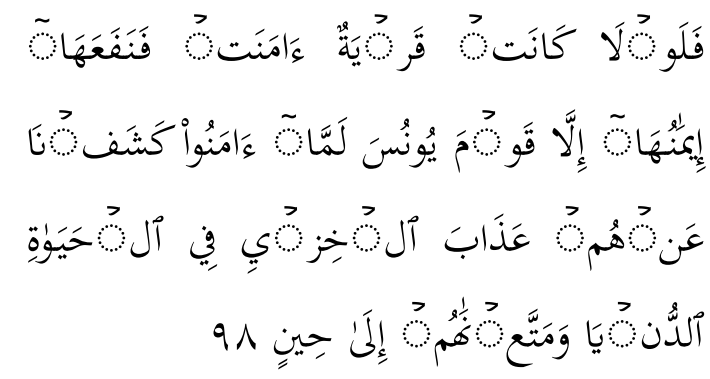

Dan mengapa tidak ada (penduduk) suatu kota yang beriman, lalu imannya itu bermanfaat kepadanya selain kaum Yunus? Tatkala mereka (kaum Yunus itu), beriman, Kami hilangkan dari mereka azab yang menghinakan dalam kehidupan dunia, dan Kami beri kesenangan kepada mereka sampai kepada waktu yang tertentu. (Q.S. Yunus/10:98).

Ayat tersebut di atas memberikan keterangan yang sangat jelas dan sebagai tafsir terhadap Surat Gafir ayat 85, bahwa iman tidak dapat menolak terhadap adzab yang Allah turunkan kepada hambanya kecuali hanya yang terjadi pada iman umat Nabi Yunus as. ${ }^{18}$ Iman yang diikrarkan umat Nabi Yunus as yaitu ketika diturunkannya bencana kepada mereka, di saat itulah mereka beriman dan di saat itu pula Allah SWT melenyapkan bencana dari hadapan mereka.

Terhadap ayat di atas Qatadah ra memberikan penafsiran bahwa keadaan seperti itu tidak pernah terjadi pada umat-umat sebelumnya sebagai mana yang terjadi pada umat Nabi Yunus as. ${ }^{19}$ dan hal itu dijelaskan oleh Abdullah bin Abbas ra, Ia mengatakan bahwa umat Nabi Yunus as. di waktu bencana turun mereka mengaku beriman dan Allah SWT menlenyapkan adzab tersebut. $^{20}$

Bantahan berikutnya adalah terhadap argumen yang dikedepankan oleh mufassir yang menyatakan bahwa Fir'aun mengucapkan kata iman itu karena keputus asaannya-dari terjangan ombak besar dan tidak ada harapan bisa selamat-. Bantahan pertama

${ }^{18}$ Ibnu 'Arabi, al-Futûhât al-Makiyah,... Jilid. 6, h. Lihat Jalaluddin Al-Dawani, Risalah Îmân Fir'aun, t.t: Mathba'ah al-Mishriyyah, 1964, h. 18

19 Jalaluddin al-Suyuti, al-Durru alMantsûr fí al-Tafsîr bi al-Ma'tsur, Cet. I, Jilid VII (Kairo: Markz Hajr li-al-Buhûts, 2003), h. 706.

${ }^{20}$ Kejadian tersebut terjadi di Ninawa yang meurpakan bagian dari wilayah Mashil. Lihat Jalaluddin al-Suyuti, al-Durru al-Mantsûr fí al-Tafsîr bi al-Ma'tsur, ...., h. 707 dan 709 . 
menurut Ibnu Arabi bahwa seandainya Fir'aun itu orang yang putus asa maka tidak mungkin dia bergegas mengucapkan iman karena untuk apa diucapkan kalau sudah tidak ada lagi harapan. ${ }^{21}$ Lebih tegas lagi Abdurrahman Nuruddin menyatakan bahwa memang sudah menjadi viral dan melekat hingga tertanam di hati kebanyakan orang yang menetapkan celaka, kufur dan masuknya Fir'aun ke dalam neraka bahkan dari sebelum Fir'aun ditenggelamkan pun mereka sudah menetapkan hal itu yaitu akan kekufuran Fir'aun dengan berdasar pada perkataan Fir'aun yang mengaku dirinya sebagai tuhan, dan banyak berbuat keburukan. ${ }^{22}$

Selain dasar-dasar tersebut di atas, Ibnu Arabi berargumen dengan Surat al-Qashas ayat $9 .{ }^{23}$ Menurutnya bahwa yang dimaksud qurratu 'ainî wa laka adalah bahwa kehadiran Musa bayi akan memberikan kesejukan dan kemanfaatan bagi Asiah dan Fir'aun. Adapun kesejukan dan manfaat bagi Fir'aun adalah dengan diberikan

${ }^{21}$ Ibnu 'Arabi, Fushush Al-Hikam,.....h. 489 .

22 Abdurrahman Ibnu Ahmad Nuruddin, al-Syarh al-Jâmi' 'alâ Fushus alHikam (Bairut: Dâr al-Kutub al-Ilmiyyah, 2004), h. 480 .

${ }^{23}$ Teks ayat sebagai berikt:

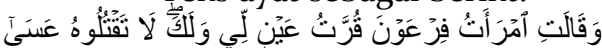

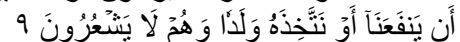

"Dan berkatalah isteri Fir'aun: "(Ia) adalah penyejuk mata hati bagiku dan bagimu. Janganlah kamu membunuhnya, mudahmudahan ia bermanfaat kepada kita atau kita ambil ia menjadi anak", sedang mereka tiada menyadari”. (Q.S al-Qashas/28:9). kesempatan iman oleh Allah SWT ketika tenggelam di laut Merah. ${ }^{24}$

Sementara

al-Dawani menegaskan bahwa ayat yang menyatakan tentang keimanan Fir'aun itu sudah jelas baik secara mantuq ataupun mafhum. Huruf lâ pada kalimat lâ ilâha illa al-ladzi âmant bihi banû isrâ'il menunjukan nafi (mentiadakan) jenis. Sedangkan khabarnya dibuang sehingga pemaknaan kalimat tersebut menjadi "saya beriman bahwa tidak ada tuhan kecuali yang diimani Bani Israil". Ungkapan tersebut jika dimaknai dengan lengkap maka menjadi "saya membenarkan dan meyakini bahwa tidak ada yang disembah dengan haq kecuali Allah yang diimani oleh Bani Israil. Dan yang diimani oleh mereka adalah yang disembah dengan hak yaitu yang dibawa oleh Musa as dan Harun as.

Adapun yang dijadikan dasar terhadap pendapatnya ada dua; pertama (secara logis) bahwa iman itu pembenaran di hati sedangkan ikrar di lisan hanya sekedar mengikuti hukum syariat, maka bagaimana mungkin orang yang sudah membenarkan di hati dan ia mengungkapkannya di lisan kemudian imannya terhalangi karena datang kematiannya. Ia juga berargumen bahwa Fir'aun tidak putus asa, jika ia putus asa maka tidak mungkin ia mengucapkan

${ }^{24}$ Ibnu Arabi, Fushus al-Hikam, ....h. 479.

Saepudin, Umar Fauzi 
keimanan tersebut. ${ }^{25}$ Bahkan Surat Yunus ayat 90 merupakan pertolongan Allah SWT kepada hambanya yang ia kehendaki sehingga hambanya tidak merasa putus asa terhadap dosa yang telah dilakukanya. Hal itu diperkuat dengan Surat al-Zumar ayat $53^{26}$ dan Surat Yusuf ayat $87 \cdot{ }^{27}$ Serta hadis Nabi SAW yang diriwayatkan oleh Imam Ibnu Majah dari Abu Hurairah r.a yang menjelaskan bahwa rahmat Allah SWT mengalahkan murkaNya.

Al-Dawani juga menjelaskan Surat Thaha ayat $39 .{ }^{28}$ Pada ayat tersebut terdapat kalimat ya'khudhu

${ }^{25}$ Jalaluddin al-Dawani, Risalah Iman Fir'aun, ....h. 17 .

${ }^{26}$ Teks ayat sebagai berikut:

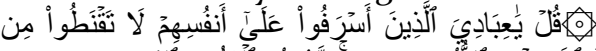

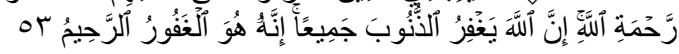

"Katakanlah: "Hai hamba-hamba-Ku yang malampaui batas terhadap diri mereka sendiri, janganlah kamu berputus asa dari rahmat Allah. Sesungguhnya Allah mengampuni dosa-dosa semuanya. Sesungguhnya Dialah Yang Maha Pengampun lagi Maha Penyayang. (Q.S al-Zumar/39:53).

${ }^{27}$ Teks ayat

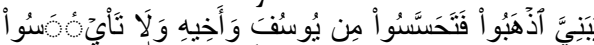

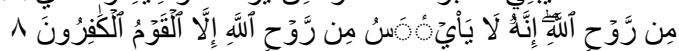

"Hai anak-anakku, pergilah kamu,

maka carilah berita tentang Yusuf dan saudaranya dan jangan kamu berputus asa dari rahmat Allah. Sesungguhnya tiada berputus asa dari rahmat Allah, melainkan kaum yang kafir". (Q.S Yusuf/12:87).

${ }^{28}$ Teks ayat sebagai berikt:

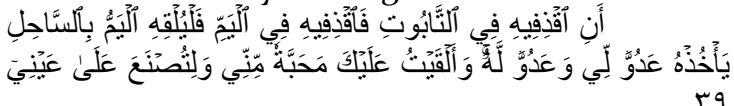

"Yaitu: "Letakkanlah ia (Musa) didalam peti, kemudian lemparkanlah ia ke sungai (Nil), maka pasti sungai itu membawanya ke tepi, supaya diambil oleh (Fir'aun) musuh-Ku dan musuhnya. Dan Aku telah melimpahkan kepadamu kasih sayang yang datang dari-Ku; dan supaya kamu diasuh di bawah pengawasanKu. (Q.S Toha/20:39). 'aduwwun lî wa 'aduwwun lahu. Yang jadi permasalahan adalah dua isim fail-subjek pelaku yaitu kalimat 'aduwwun-pada kalimat tersebut adalah talabbus (tidak ditentukan pada seseorang/berkemungkinan kepada siapa yang dituju). Bahkan kalimat tersebut merupakan majaz sedangkan majaz harus ada qarinah yang menjadi penunjuk terhadap yang dituju. Sedangkan qarinah yang menunjukan Fir'aun mati dalam keadaan kafir pun tidak dijumpai.. ${ }^{29}$

Sedangkan yang dimaksud dengan "idzâ hadhara ahadahum almaut" dalam Surat al-Nisa ayat 18 . Al-Dawani meberikan bantahan terhadap pernyataan dan argument mereka. Menurutnya yang dimaksud dengan al-maut pada penggalan ayat "idzâ hadhara ahadahum al-maut" adalah malaikat, itulah yang ditafsirkan oleh para mufassir. Dan seandainya yang dimaksud al-maut itu adalah kematian maka berarti ruh itu sampai kepada gargarah dan ini tidak bisa dijadikan dasar yang paten untuk tidak diterimanya iman Fir'aun karena kalimat -inni tubtu alana-tidak diikrarkan Fir'aun namun yang dia ucapkan adalah âmantu annahu la ilâha illa al-ladzi âmanat bihi banû isrâ'il wa ana min almuslimin. Kalimat ini menjadi penunjuk bahwa dia berucap tidak di waktu gargarah terbukti dengan bentuk kalimat ungkapannya. Sangat tidak logis jika kalimat yang begitu banyak-sampai tiga pernyatan

${ }^{29}$ Jalaluddin Al-Dawani, Risalah Iman Fir'aun,... h. 19. 
sebagaimana telah disebutkan pada pembahasan sebelumnyadisandarkan bahwa kalimat tersebut diungkapkan ketika seseorang dalam keadaan menghadapi bahaya besar. ${ }^{30}$ Terhadap ayat tersebut (alNisa/4:18) Abu Hatim mengomentarinya dengan meriwayatkan hadis dari Ayyub bahwa ia mendengar Abdullah bin Amr berkata: "Barang siapa yang bertaubat setahun sebelum kematiannya maka diterima taubatnya, begitu pun yang bertaubat sebulan sebelum kematiannya, satu minggu sebelum kematiannya, satu hari sebelum kematiannya, satu sa'ah (sekon) bahkan lebih dekat dari itu. Kemudian Ayyub berkata: "Subhânallah tidakkah Allah SWT berfirman: "Dan tidaklah taubat itu diterima Allah dari orang-orang yang mengerjakan kejahatan (yang) hingga apabila datang ajal kepada seseorang di antara mereka". Kemudian Abu Amr berkata: "sesungguhnya yang aku sampaikan kepadamu adalah yang aku dengar dari Rasulullah SAW". ${ }^{31}$

Dengan batas akhir yang ditegaskan dalam hadis tersebut di atas sudah sangat jelas bahwa batas akhir taubat bagi seorang hamba adalah gargarah yang dijelaskan pada hadis yang diriwayatkan Ibnu 'Umar. Kenapa waktu ghargarah tersebut sebagai batas akhir bagi

${ }^{30}$ Jalaluddin Al-Dawani, Risalah Iman Firaun,.... h. 20.

${ }^{31}$ Abu Hatim, Tafsir al-Qur'an al'Adhim,.... h. 900. taubat dan sebelum ruh sampai ditenggorokan ikrar keimanan dan taubat seorang hamba masih dapat diterima. Permasalahan tersebut dijelaskan Ibnu Rajab al-Hanbali dalam karyanya Rawa'i al-Tafsir. Menurutnya, ketika kematian belum sampai di gargarah tentu belum terbuka semua tabir alam gaib yang harus diimani oleh setiap hamba. Dan saat seperti itu tentu masih ada kesempatan untuk bertaubat karena yang dimaksud dengan taubat ketika datang kematian yaitu taubat yang dilakukan ketika terbukanya tabir yang gaib serta terlihat nampak di hadapannya segala yang ada tentang urusan akhirat, dan pada saat itu mereka juga dapat menyaksikan malaikat.

Sudah menjadi ketentuan bahwa iman, taubat dan seluruh amal perbuatan hanya dapat dapat diterima dengan sebab masih ada waktu yaitu masih tertutupnya halhal yang gaib-yang bersifat rahasia Allah SWT (al-Baqarah/2:3). Maka jika tabir penghalang sudah dibuka dan yang gaib menjadi nyata maka iman dan taubat di saat itu tidak lagi bermanfaat. ${ }^{32}$ Sebagaimana firman Allah SWT:

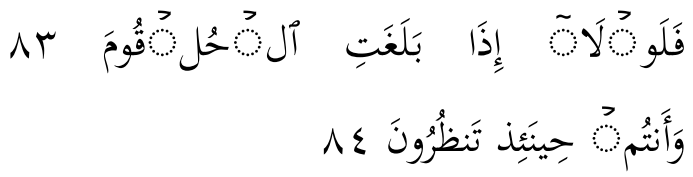

Maka mengapa ketika nyawa sampai di kerongkongan. 84. padahal kamu

${ }^{32}$ Tafsir Ibnu Rajab Al-Hanbali, Rawẩi Al-Tafsîr, Juz I (Riyad: Dar Al-Âshimah, 2001), h. 301. 
ketika itu melihat. (Q.S alWaqi'ah/56: 83-84).

Larangan putus asa pada ayat

Ayat di atas menerangkan bahwa ketika datang kematian dan ruh sudah sampai di tenggorokan maka di waktu tersebut akan diperlihatkan segala hal yang gaib dan semuanya menjadi terlihat nyata itulah yang dimaksud dengan gargarah.

Adapun yang dimaksud dengan istilah al-îmân al-ya's iman putus asa yang tidak bermanfaat secara syar'i yaitu iman di hari kiamat dan itu menjadi sunnah Allah dan jika tidak seperti itu berarti firman-Nya bohong karena Allah berfirman Surat Yunus ayat 98. Dan selama manusia itu masih memiliki ruhketika hidup di bumi-maka istilah alîmân al-ya's itu tidak ada. Oleh sebab itu jika disebutkan iman putus asa yang disandarkan dengan hidup di bumi maka iman putus asa tersebut masih tetap diterima dengan dalil Surat al-Zumar ayat 53:

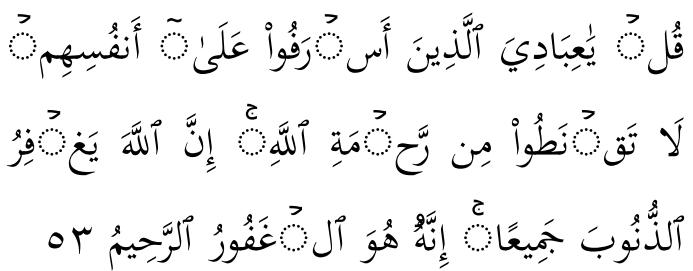

Katakanlah: "Hai hamba-hamba-Ku yang malampaui batas terhadap diri mereka sendiri, janganlah kamu berputus asa dari rahmat Allah. Sesungguhnya Allah mengampuni dosa-dosa semuanya. Sesungguhnya Dialah Yang Maha Pengampun lagi Maha Penyayang. (Q.S alZumar/39:53). di atas menegaskan bahwa siapapun hendaknya untuk tidak putus asa dari rahmat Allah SWT disebabkan dengan banyaknya berbuat dosa karena Allah SWT maha pengampun dan penyayang. Dan perlu dipahami bahwa keputusasaan yang muncul pada seseorang akan menghilangkan semua harapan sehinnga Fir'aun pun seandainya ia putus asa tentu ia tidak akan berikrar.

Dengan menelaah Surat Yunus/10:90 jelaslah bahwa Fir'aun memiliki kesempatan waktu untuk ia dapat mengikrarkan keimanannya dan ketundukan kepada sang pencipta, Allah SWT. Adapun pendapat yang mengatakan bahwa pengakuan iman yang terucap di lisan Fir'aun tidak diterima karena ucapan keimanannya tersebut disandarkan kepada apa yang diimani Bani Irail sedangkan menurut mereka Bani Israil di saat itu menyembah patung ijil-. Maka alasan seperti itu sebenarnya kurang tepat disebabkan beberapa hal; pertama, karena penyembahan terhadap 'ijil yang dilakukan Bani Israil adalah setelah terjadinya eksodus, sedangkan sebelum eksodus mereka belum mengenal terhadap 'ijil dan tentulah mereka mengimani apa yang diimani Musa as. dan Harun as.

Hal itu dijelaskan dalam Surat al-'Araf/7:138.

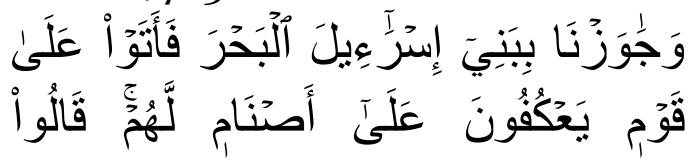




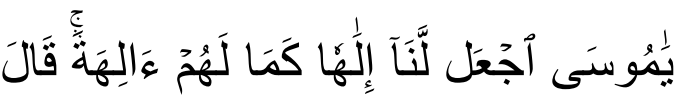

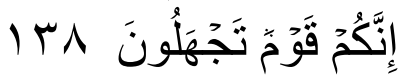

Dan Kami seberangkan Bani Israil ke seberang lautan itu, maka setelah mereka sampai kepada suatu kaum yang tetap menyembah berhala mereka, Bani lsrail berkata: "Hai Musa. buatlah untuk kami sebuah tuhan (berhala) sebagaimana mereka mempunyai beberapa tuhan (berhala)". Musa menjawab: "Sesungguh-nya kamu ini adalah kaum yang tidak mengetahui (sifatsifat Tuhan)". (Q.S al-A'raf/7:138).

Ayat di atas memberikan ketegasan bahwa Bani Israil setelah diselamatkan di lautan dari kejaran Fir'aun mereka melewati sekelompok manusia yang sedang melakukan ritual peribadatan menyembah berhala. Hal itu dapat dilihat dari dua kalimat pada ayat di atas yaitu kalimat wa jâwaznâ yang berarti Allah lewatkan dan fa'ataû yang berarti mereka mendatangi. Dua kalimat tersebut meberikan pemahaman bahwa Bani Israil melewati lautan dan kemudian baru mereka menjumpai kelompok orang yang sedang menyembah berhala. Jadi peristiwa yang mereka saksikan itu yang memberikan inspirasi kepada mereka untuk membuatkan patung sebagai bentuk nyata tuhan yang mereka imani. Setelah kejadian itu baru Bani Israil meminta kepada Musa as. untuk dibuatkan patung berhala sebagai perantara mereka untuk menyembah kepada Tuhan. ${ }^{33}$

Begitu juga jika dilihat dari segi kebahasaan. Dinamai dengan ijil disebabkan Bani Israil ingin bercepat-cepat melakukan ituuntuk mebuatkan patung sebagai gambaran tuhan yang dapat dijadikan perantara mereka dalam penyembahan-sebelum Musa as kembali dari ibadahnya di Sinai. ${ }^{34}$ Dan itu terjadi setelah lama Bani Israil meninggalkan kota Mesir.

Ayat lain yang menjelaskan hal tersebut adalah:

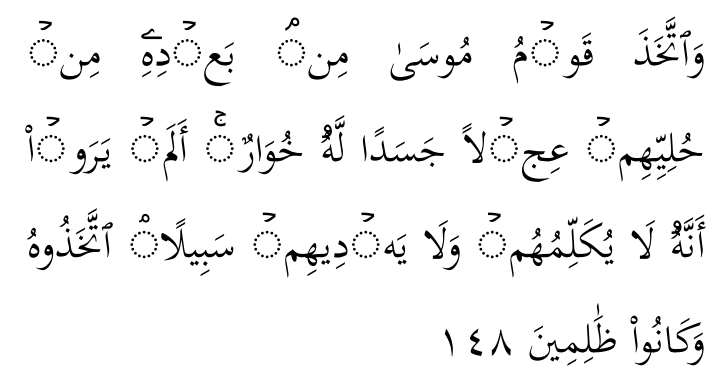

Dan kaum Musa, setelah kepergian Musa ke gunung Thur membuat dari perhiasan-perhiasan (emas) mereka anak lembu yang bertubuh dan bersuara. Apakah mereka tidak mengetahui bahwa anak lembu itu tidak dapat berbicara dengan mereka dan tidak dapat (pula) menunjukkan jalan kepada mereka? Mereka menjadikannya (sebagai sembahan) dan mereka adalah orang-orang yang zalim. (Q.S al-'Araf/7 :148).

Ayat kedua memberitahukan dengan uraian yang sangat rinci

${ }^{33}$ Muhammad Abduh, Tafsîr Al-Manâr, Cet. II, Juz IX (Kairo: Dar al-Manar, 1367), h. 108.

34 Ibnu 'Atiyyah al-Andalusi, alMuharrar al-Wajîz, Juz I, t.t., h. 145. 
bahwa umat Nabi Musa as. membuat ‘jil dari perhiasan-perhiasan mereka lalu dibentuk patung berbadan dan mampu bersuara untuk mereka sembah. ${ }^{35}$ Itu sebab pertama.

Alasan kedua, kelompok yang dikejar Fir'aun adalah Bani Israil sedangkan Musa as. dan Harun as. ada di barisan depan dan mereka berdua tidak diketahui oleh Fir'aun oleh sebab itu pantaslah yang diucap Fir'aun adalah tuhan Bani Israil dan tidak menyebut Tuhan Musa as. berbeda halnya yang terjadi terhadap para penyihir Fir'aun, mereka ketika terjadi kekalahan dari Musa as dalam beradu sihir langsung berikrar untuk beriman dengan ucapan iman yang disandarkan kepada tuhan yang mengatur alam dan mengurus Musa as. dan Harun as. Mereka mengucapkan kalimat tersebut karena di saat itu mereka langsung berhadapan dengan Musa as. dan Harun as.

Ada juga yang mengatakan bahwa pengakuan iman yang diucapkan Fir'aun yaitu perkataan $b i$ al-ladzî âmanat bihi banû isrâil adalah merupakan bukti bahwa yang diimaninya adalah bentuk taklid atau hanya sekedar mengikuti apa yang yang diyakini oleh Bani Israil. Hal itu hanya dengan harapan

35 Jalaluddin al-Suyuti menambahkan bahwa perhiasan yang digunakan untuk membuat patung ijil adalah perhiasan yang mereka pinjam dari pengikut Fir'aun dan sempat mereka bawa ketika terjadi eksodus. Jalaludin al-Suyti dan Jalaluddin Al-Mahalli, Tafsir al-Jalâlain al-Muyassar, Juz I (Bairut: Maktabah Lubnan Nasyirun, 2003), h. 168. supaya ia ikut selamat dari tenggelam. ${ }^{36}$ Padahal sudah jelas bahwa jika seseorang sudah Allah tentukan untuk menjadi orang yang celaka di akhirat maka Allah tentukan juga dia untuk tidak akan beriman.

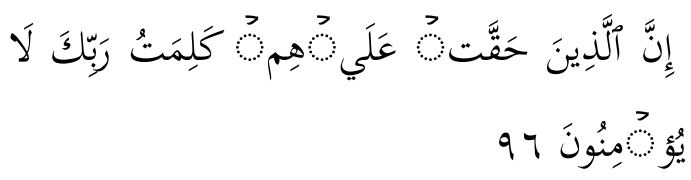

Sesungguhnya orang-orang yang telah pasti terhadap mereka kalimat Tuhanmu, tidaklah akan beriman. (Q.S. Yunus/10:96).

Kata kalimatu rabbik ditafsirkan bahwa mereka sudah ditentukan menjadi ahl al-syaqawah (orang yang celaka di akhirat). Terhadap orang seperti itu tidak akan ada manfaatnya walaupun diberikan kepadanya dalil-dalil kebenaran yang ditunjukan kepadanya. ${ }^{37}$ Termasuk ombak besar yang dapat menelan semua pengikut-pengikut Fir'aun.

Orang yang dikehendaki atau yang sudah ditetapkan jadi penghuni neraka atau orang sudah ditetapkan akan mendapat adzab Allah SWT pastilah ia tidak akan diberi kesempatan utuk beriman walaupun kesempatan itu ada baginya seperti orang-orang yang diberi kesempatan untuk berucap ketika menjelang

${ }^{36}$ Al-Barusawi Ismail Haqqi, Tafsîr Rûh al-Bayân, Jilid IV (Utsmaniyyah Mathba'ah, 1330), h. 76.

${ }^{37}$ Hikmat bin Basyir bin Yasin, al-Tafsîr al-Sahîh: Mausâ'ah al-Sahîh al-Masbûr min alTafsîr bi al-Ma'tsûr, Jilid III (Madinah: Dâr alMa'âtsir, 1419), h. 33. 
kematiannya namun hal itu tidak mau ia ucapkan. Bahkan tidak akan dia beriman atau dia tidak mau mengikrarkan keimanan tersebut walaupun datang adzab di hadapannya. Allah SWT berfirman:

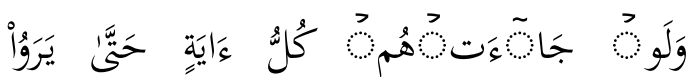

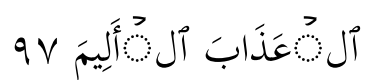

Meskipun datang kepada mereka segala macam keterangan, hingga mereka menyaksikan azab yang pedih. ( Q.S. Yunus/10: 97).

Penggunaan kata lau dalam kaidah bahasa Arab adalah sebagai kata yang bermakna al-imtinâ' (penolakan). Dengan kata lain kata lau memberikan makna pengandaian yang sekaligus memberikan makna sesuatu yang tidak akan terjadi..$^{8}$ Sedangkan kata hatta sebagai intihâ al-ghâyah (penentuan yang paling akhir). ${ }^{39}$ Dengan dua makna yang terkandung pada dua kata pada ayat di atas menunjukan bahwa ketetapan Allah SWT adalah segalanya. Jadi orang-orang yang sudah ditentukan untuk celaka di akhirat kelak ia tidak akan beriman walaupun adzab yang dahsyat ditimpakan kepada mereka. Dan begitu pula orang yang sudah ditentukan untuk kafir maka ia tidak akan mampu untuk mengikrarkan ketauhidan di akhir hayatnya.

${ }^{38}$ Ibnu Hisyam al-Anshari, Mughnî alLabîb, Juz I (Bairut: al-Maktabah al-'Ashriyyah, 1991), h. 284.

39 Ahmad bin Hasyab, al-Murtajal fi Syarh al-Jumal, Juz II (Damaskus: Majma' alLughah al-'Arabiyyah, 1972), h. 173.

\section{Penutup}

Dari pemaparan di atas penulis dapat menyimpulkan bahwa al-Qur'an banyak menjelaskan tentang bagaimana kehidupan Fir'aun baik dari kepribadian atau identitas diri serta karakternya yang menunjukan bahwa ia seorang raja yang menguasai negeri Mesir dengan memiliki sifat-sifat buruk, baik dari segi sosial ia sebagai pemimpin, dan atau secara pribadi yaitu dalam berkeyakinan. Selain itu Fir'aun juga melakukan penentangan terhadap ajakan ajaran tauhid yang disampaikan Musa as dan Harun as kepadanya. Namun kendati demikian Allah SWT yang punya kehendak terhadap segalanya dan Dzat yang melakukan apa yang Dia kehendaki. Dia memberikan ketetapan terhadap akhir ajal yang menimpa Fir'aun. Allah SWT memberikan kesempatan kepadanya untuk mengungkapkan pernyataan iman dan ketundukan kepada-Nya. Oleh sebab itu menurut sebagian sufistik menyatakan bahwa Fir'aun mendapat kesempatan untuk bertaubat kepada Allah SWT dan mengakhiri kekufurannya dengan berikrar iman dan menyatakan dirinya tunduk kepada Allah SWT karena ia berikrar ketika ruh belum sampai di ghargarah (tenggorokan). Sedangkan menurut mayoritas mufasir, mereka menyatakan bahwa keimanan dan ketundukan yang diikrarkan Fir'aun ketika menjelang ajalnya tidak diterima oleh Allah SWT dengan sebab ia bertaubat di waktu tidak diterimanya taubat. 


\section{Daftar Pustaka}

Abduh, Muhammad. Tafsîr Al-Manâr.

Cet. II, Juz IX. Kairo: Dar al-

Manar, 1367.

Abdurrahman Ibnu Ahmad Nuruddin. al-Syarh al-Jâmi' 'alâ Fushus alHikam. Bairut: Dâr al-Kutub alIlmiyyah, 2004.

Afganii, Syamsuddin al-Salafii al-. Juhûdu 'Ulama al-Hanafiyyah fí Ibthâl 'Aqầid al-Qubûriyyah. Riyad: Dar as-Syami'i, 1996.

Ahmad bin Hasyab. al-Murtajal fi Syarh al-Jumal. Juz II. Damaskus: Majma' al-Lughah al-'Arabiyyah, 1972.

Al-Dawani, Jalaluddin. Risalah Iman Fir'aun. Cet. I. Mathba'ah alMishriyyah, 1964.

Al-Hanbali, Tafsir Ibnu Rajab. Rawầi Al-Tafsîr. Juz I. Riyad: Dar AlÂshimah, 2001.

Andalusi, Ibnu 'Atiyyah al-. alMuharrar al-Wajîz. Juz I., t.t.

Anshari, Ibnu Hisyam al-. Mughnî alLabîb. Juz I. Bairut: al-Maktabah al-'Ashriyyah, 1991.

Arabi, Ibnu. al-Futûhât al-Makiyyah. Jilid VI, Bab ke 386., t.t.

'Asyur, Ibnu. Tafsir al-Tahrir wa alTanwir. Juz XI., t.t.

Faris, Ibnu al-. Mu'jam Maqâyîs alLughah. Jilid I. Bairut: Dar al-Jail, t.t.

Hikmat bin Basyir bin Yasin. al-Tafsîr al-Sahîh: Mausâ'ah al-Sahîh alMasbûr min al-Tafsîr bi alMa'tsûr. Jilid III. Madinah: Dâr al-Ma'âtsir, 1419.

Ismail Haqqi, Al-Barusawi. Tafsîr Rûh al-Bayân. Jilid IV. Utsmaniyyah Mathba'ah, 1330.

Muhammad bin Ahmad al-Qurtubi. alJâmi' al-Ahkâm al-Qu'rân. Jilid IV. Bairut: Maktabah alMuassasah, 2006.
Muhtolib. "Wawasan Al-Qur'an tentang Respon Iblis terhadap Perintah Sujud (Sebuah Pendekatan Teologis dan Sufistik)." Diakses 3 Desember 2021. https://scholar.google.co.id/citat ions?view_op=view_citation\&hl= id\&user=IIUM4c4AAAAJ\&citatio n_for_view=IIUM4c4AAAAJ:u5H HmVD_uO8C.

Muttakin, Ali. "Kaidah Kebahasaan Dalam Kajian Tafsir." Al-Bayan: Jurnal Studi Ilmu Al- Qur'an Dan Tafsir 1, no. 2 (30 Desember 2016): 79-90. https://doi.org/10.15575/albayan.vii2.1594.

- - C. "Kedudukan Kaidah Kebahasaan dalam Kajian Tafsir." Diakses 2 Desember 2021.

https://scholar.google.com/citati ons?view_op=view_citation\&hl=i d\&user=A_vieQcAAAAJ\&citatio n_for_view=A_vieQcAAAAJ:MX K_kJrjxJIC.

rani, Abd al-Wahab al-Sya'. al-Yawaqit wa al-Jawahir. Juz II. Bairut: Dar al-Kutub al-Ilmiyyah, 2013.

Suyti, Jalaludin al-, dan Jalaluddin AlMahalli. Tafsir al-Jalâlain alMuyassar. Juz I. Bairut: Maktabah Lubnan Nasyirun, 2003.

Suyuti, Jalaluddin al-. al-Durru alMantsûr fí al-Tafsîr bi al-Ma'tsur. Cet. I, Jilid VII. Kairo: Markz Hajr li-al-Buhûts, 2003.

Thabari, Ibnu Jarir al-. Tafsîr alThabari, Jâmi al-Bayâ. Juz Xii. Kairo: Dâr Hijr, 2001. 
Waliyullah, Muhammad. "Pemahaman

Dan Penerapan Ayat-Ayat

Multikulturalisme." Diakses 3

Desember

2021.

https://scholar.google.com/citati

ons?view_op=view_citation\&hl=i

d\&user=vjaQbQIAAAAJ\&citatio

n_for_view=vjaQbQIAAAAJ:u5H

HmVD_uO8C. 